\title{
The Knowledge and Attitude of the Community from the Aseer Region, Saudi Arabia, Toward COVID-19 and Their Precautionary Measures Against the Disease
}

This article was published in the following Dove Press journal:

Risk Management and Healthcare Policy

\author{
Arwa Khaled (1D) ${ }^{1,2}$ \\ Ayesha Siddiqua $\mathbb{D I}^{\prime}$ \\ Soha Makki (iD)' \\ 'Department of Clinical Pharmacy, \\ College of Pharmacy, King Khalid \\ University, Abha, Saudi Arabia; \\ ${ }^{2}$ Department of Clinical Pharmacy, Beni- \\ Suef University Hospital,Beni-Suef \\ University, Beni Suef 625I5, Egypt
}

Background: Community adherence to current control measures is one of the vital factors that determines the success of controlling the spread of COVID-19. This adherence depends on the knowledge and attitude of a community toward COVID-19 and their precautionary measures against the disease.

Objective: This study aims to evaluate the knowledge and attitude of the community from the Aseer Region, Saudi Arabia, toward COVID-19 and their precautionary measures against the disease.

Methods: The descriptive cross-sectional study involved an online sample of participants from the Aseer Region, Saudi Arabia, who were recruited based on a nonprobability convenience sampling method from April to May 2020. The self-administered online questionnaire comprised four parts: the first included the demographic details of the participants; the second consisted of 11 closed-ended questions that assessed the participants' knowledge of COVID-19; the third contained six closed-ended questions that assessed the participants' overall attitude toward COVID-19; and the fourth comprised six closed-ended questions on the participants' precautionary measures against COVID-19. The data were analyzed using Statistisoftware SPSS 21.0. Results: Altogether, 740 participants completed the online questionnaire. The mean knowledge score concerning COVID-19 was $8.08 \pm 1.765$. Graduate participants scored significantly higher for all knowledge items than those from other educational levels. Furthermore, the main source of COVID-19 information was the Ministry of Health website $661(89.3 \%)$. The mean attitude score regarding COVID-19 was $9.74 \pm 1.935$, whereas the mean precautionary measures score was $10.09 \pm 1.91$. University-educated participants scored significantly higher for all knowledge items than those from other educational levels. Female participants had significantly higher precautionary measures scores than male participants.

Conclusion: This study confirms that residents of the Aseer Region have high knowledge of, demonstrate a positive attitude toward, and use appropriate precautionary measures against COVID-19, which is associated with obtaining information about the virus from the Ministry of Health website.

Keywords: knowledge, attitude, precautionary measures, coronavirus

\section{Introduction}

Coronavirus disease 2019 (COVID-19) was first identified in Wuhan, China, in December 2019. It is a highly infectious emerging respiratory disease caused by a novel beta coronavirus, so-called SARS-CoV-2, with evident symptoms of 
a sudden onset of fever, fatigue, dry cough, myalgia, and dyspnea. ${ }^{1-3}$ This epidemic disease spread rapidly and had reached around 215 countries by August 16, 2020, leading to $21,294,845$ confirmed cases and 761,779 deaths. ${ }^{4}$ On January 30, the World Health Organization (WHO) declared that this novel coronavirus outbreak is a public health emergency of international concern. ${ }^{5}$ The first case of COVID-19 in Saudi Arabia was reported on March 3, 2020, and by May 13, the confirmed cases had risen to 42,925 , with a death total of $264 .^{6,7}$

While the transmission of COVID-19 occurs mainly through the respiratory route or contact with infected secretions, ${ }^{3}$ it can also be transmitted via nosocomial spread. ${ }^{8}$ The basis of controlling the outbreak of this disease is implementing measures that could decrease its transmission, including isolation, quarantine, social distancing, and community containment. ${ }^{9}$ The Kingdom of Saudi Arabia (KSA) was quick to adopt unprecedented measures to control the transmission; for instance, the KSA placed restrictions on the inbound Umrah pilgrimage on February 27, 2020. The kingdom also suspended the recently introduced e-Visa program, banned the inbound travel of persons from COVID-19-affected countries, and restricted the travel of Gulf Cooperation Council (GCC) citizens who had recently traveled to COVID-19-affected countries. ${ }^{10}$ Finally, all schools, universities, and mosques throughout the kingdom were closed. ${ }^{11,12}$

One of the central factors that affect the success of controlling COVID-19 is community adherence to the control measures that the government and the Ministry of Health (MOH) have instigated. This adherence depends on the community's knowledge and attitude toward COVID19, which helps in dealing with pandemics as per evidence. ${ }^{13}$ Assessing public knowledge helps in identifying gaps and strengthening the prevention efforts that are in progress. According to the researcher's knowledge, there are no studies done to evaluate adherence to the control measures in the Aseer Region in particular; thus, the authors investigate residents of the Aseer Region, Saudi Arabia, regarding their knowledge of, attitude toward, and precautionary measures against the disease during the rapid rise of the current outbreak.

\section{Methodology}

\section{Study Design and Setting}

This cross-sectional online study was designed to assess the level of knowledge and overall attitude of the community from the Aseer Region, Saudi Arabia, toward COVID-19 and their precautionary measures against the disease.

\section{Target Population, Sampling Criteria, and Sample Size}

The Aseer Region, in the southern province of Saudi Arabia, has a population of about 2.26 billion as per the Saudi MOH Statistical Yearbook 2018. ${ }^{14}$ The respondents were recruited based on the nonprobability convenience sampling method. The estimated minimum target sample size was 664, which was calculated using the Raosoft sample size calculator, with a confidence interval of $95 \%$, a limit of $5 \%$ precision, and a design effect of 1.0 . The inclusion criteria were as follows: Saudis/non-Saudis and male/female residents of the Aseer Region, Saudi Arabia. Those residing outside the Aseer Region were excluded from the study.

\section{Survey Instrument Development and Data Collection}

A self-administered structured questionnaire based on instruments used in previous studies on similar conditions (ie, MERS-CoV, SARS-Co-V, and COVID-19) was adapted by conducting an extensive literature review. ${ }^{15-}$ ${ }^{20}$ Focus group discussions were held by conducting an informal online discussion with participants to understand their perceptions, beliefs, fears, questions, and information needs regarding the new coronavirus outbreak. Vulnerable groups like people with chronic diseases, older adults were also part of this focus group discussion. Suggestions were taken, and a final questionnaire was prepared to fulfill the objective of this study. The questionnaire was translated into the Arabic language for the participants' convenience, as it is the native language of most residents of the Aseer Region. The questionnaire was then subjected to a face and content validation process involving expert advice to ensure that it was comprehensive. The questionnaire's internal consistency was also evaluated, and a Cronbach's alpha value of 0.729 was obtained using SPSS, which indicates that the questionnaire is reliable.

The questionnaire was piloted with ten respondents representing the study population to determine the clarity of the language and the structure of the questionnaire. The pilot study results were not included in the final results; nevertheless, the feedback was analyzed, the doublebarreled, confusing, and leading questions were modified, 
and a finalized questionnaire was created. This finalized questionnaire was based on the study's objectives and the prospect of the respondents to complete the entire survey. Respondents' names were not requested to maintain anonymity and elicit unbiased responses that should better reflect the respondents' opinions. The questionnaire was converted into a web-based format (Google Forms) and delivered to the participants in English and Arabic through social networking websites. Eligible participants were approached, and the questionnaire portal was closed when the number of participants exceeded the sample size (ie, after about two weeks in April and May 2020).

The questionnaire comprised four parts: The first included the demographic details of the participants, who provided information on their ages, genders, nationalities, and education levels and disclosed whether they had any comorbidities, such as hypertension, diabetes mellitus, respiratory disease, cardiac disease, or any other chronic disease. The second part consisted of 11 closed-ended questions presented in a yes/no/I do not know format that assessed the participants' knowledge of COVID-19. The third part contained six closed-ended questions presented in a yes/no/sometimes/maybe format that assessed the participants' overall attitude toward COVID-19, whereas the fourth comprised six closed-ended questions presented in a yes/no/sometimes format that assessed their precautionary measures against COVID-19.

The dependent variables in this study were respondents' knowledge of, attitude toward, and precautionary measures against COVID-19. The independent variables in this study were the respondent's age, gender, nationality, education levels, and comorbid conditions. Participant responses were summed, and the KAP scores were calculated for each participant. The original Bloom's cut-off points, $80.0-100.0 \%, 60.0-79.0 \%$, and $\leq 59.0 \%$, were adapted and modified from the KAP study conducted on dengue fever prevention among the people of Male, Maldives and Bangkok in 2007 and a KAP study conducted on COVID-19 among Chronic Disease Patients, Northwest Ethiopia in 2020. ${ }^{21,22}$

For the knowledge section (total score: 10), each correct response (yes) was assigned a score of 1, and incorrect responses (no and I do not know) were assigned a score of 0. Participants' overall knowledge score was categorized using Bloom's cut-off point, as good for a score between 8 and 10 points, moderate for a score between 6 and 7.9 points, and poor for a score of less than $<6$ points. For the attitude section (6 questions, total score: 12), yes, was assigned a score of 2, sometimes and maybe were assigned a score of 1 , and no was assigned a score of 0 . The total attitude score was categorized using the same Bloom's cutoff point, as positive for a between 9.6 and 12 points, moderate for a score between 7.2 and 9.5 points, and negative for a score of less than $<7.2$ points. For the precautionary measures section (6 questions, total score: 12), yes was assigned a score of 2 , sometimes a score of 1 , and no a score of 0 . The total score was categorized using the same Bloom's cut-off point, as appropriate for a score between 9.6 and 12 points, moderate for a score between 7.2 and 9.5 points, and inappropriate for a score of less than $<7.2$ points.

\section{Statistical Analysis}

Results were downloaded and stored in Microsoft Excel spreadsheets. While the minimum target sample size was 664, data were collected from about 740 participants. The data were analyzed using SPSS 21.0 statistical software (IBM Inc., Chicago, USA). Results were described in terms of frequencies, using descriptive statistics. A chisquare test was conducted to assess the correlation between the demographic variables and the dependent variables, including the participants' knowledge, attitude, and precautionary measures. A p-value $<0.05$ was considered significant.

\section{Ethical Approval}

Ethical approval was obtained from the College of Medicine, King Khalid University, on April 19, 2020, with an approval number (ECM\#2020-222)-(HAPO-06B-001). Informed consent was likewise obtained from the participants or their parents before their participation, which was purely voluntary, with no incentives offered for participation.

\section{Results}

\section{Demographics and Clinical Characteristics}

Altogether, 740 participants completed the online questionnaire. Of these participants, $655(88.5 \%)$ were female, and $85(11.5 \%)$ were male. Moreover, 532 (70.5\%) were university-educated, 139 (18.7\%) were in high school, 52 (7\%) were postgraduates, $18(2.4 \%)$ were in secondary school, and $10(1.3 \%)$ were in primary school. Most of the participants $(695,93.7 \%)$ were Saudi, while the rest $(47,6.3 \%)$ were non-Saudi, and most $(450,60.6 \%)$ were in the same 
age group (30-50 years old). The age ranges (18-70) for other clinical characteristics are listed in Table 1.

\section{Knowledge of COVID-19}

Participants' knowledge of COVID-19 was assessed using 10 questions with scores ranging from 1 to 10 points. Participants with scores above 6 were considered to have good knowledge. The percentage of the correct answers to the 10 questions on the COVID-19 knowledge questionnaire was $80.8 \%(8.08 / 10 * 100)$. The mean knowledge score was $8.08 \pm 1.765$, whereas the median knowledge score was 8 (range $=0-10$ ). University-educated participants scored significantly higher for all knowledge items than those from other educational levels (see Table 2); however, knowledge scores did not differ significantly across age groups, except for item K10. Male participants had higher scores for items $\mathrm{K} 1, \mathrm{~K} 8$, and $\mathrm{K} 9$ than female participants, while female

Table I Baseline Demographics and Clinical Characteristics

\begin{tabular}{|c|c|c|}
\hline Characteristics & $\mathbf{N}$ & $\%$ \\
\hline \multicolumn{3}{|l|}{ Gender } \\
\hline Female & 655 & 88.5 \\
\hline Male & 85 & 11.5 \\
\hline \multicolumn{3}{|l|}{ Age (years) } \\
\hline$<18$ & 8 & 1.1 \\
\hline $18-30$ & 187 & 25.3 \\
\hline $31-50$ & 447 & 60.4 \\
\hline $5 \mathrm{I}-70$ & 97 & 13.1 \\
\hline \multicolumn{3}{|l|}{ Educational Level } \\
\hline University-education & 526 & 71.1 \\
\hline High School & 136 & 18.4 \\
\hline Postgraduate & 51 & 6.9 \\
\hline Primary School & 10 & 1.4 \\
\hline Secondary School & 17 & 2.3 \\
\hline \multicolumn{3}{|l|}{ Do you have hypertension? } \\
\hline No & 699 & 94.5 \\
\hline Yes & 41 & 5.5 \\
\hline \multicolumn{3}{|l|}{ Do you have a respiratory disease? } \\
\hline No & 680 & 91.9 \\
\hline Yes & 60 & 8.1 \\
\hline \multicolumn{3}{|l|}{ Do you have diabetes mellitus? } \\
\hline No & 684 & 92.4 \\
\hline Yes & 56 & 7.6 \\
\hline \multicolumn{3}{|l|}{ Do you have a cardiac disease? } \\
\hline No & 726 & 98.1 \\
\hline Yes & 14 & 1.9 \\
\hline
\end{tabular}

Abbreviations: N, number of participants; \%, percentage.
Table 2 Knowledge of COVID-19 Among Residents of the Aseer Region

\begin{tabular}{|c|c|c|c|c|}
\hline Variable & Options & Score & $\mathbf{N}$ & (\%) \\
\hline $\mathrm{KI}$. COVID-19 is caused by a virus. & $\begin{array}{l}\text { Yes } \\
\text { No } \\
\text { I do not } \\
\text { know }\end{array}$ & $\begin{array}{l}1 \\
0 \\
0\end{array}$ & $\begin{array}{l}621 \\
12 \\
107\end{array}$ & $\begin{array}{l}83.9 \\
1.6 \\
14.5\end{array}$ \\
\hline $\begin{array}{l}\text { K2. The signs of COVID-19 are similar } \\
\text { to those of the flu. }\end{array}$ & $\begin{array}{l}\text { Yes } \\
\text { No } \\
\text { I do not } \\
\text { know }\end{array}$ & $\begin{array}{l}1 \\
0 \\
0\end{array}$ & $\begin{array}{l}504 \\
187 \\
49\end{array}$ & $\begin{array}{l}68.1 \\
25.3 \\
6.6\end{array}$ \\
\hline $\begin{array}{l}\text { K3. COVID-19 can be transmitted } \\
\text { through cough droplets. }\end{array}$ & $\begin{array}{l}\text { Yes } \\
\text { No } \\
\text { I do not } \\
\text { know }\end{array}$ & $\begin{array}{l}1 \\
1 \\
0\end{array}$ & $\begin{array}{l}528 \\
102 \\
110\end{array}$ & $\begin{array}{l}71.4 \\
13.8 \\
14.9\end{array}$ \\
\hline $\begin{array}{l}\text { K4. COVID- } 19 \text { can be transmitted by } \\
\text { shaking hands with others. }\end{array}$ & $\begin{array}{l}\text { Yes } \\
\text { No } \\
\text { I do not } \\
\text { know }\end{array}$ & $\begin{array}{l}1 \\
0 \\
0\end{array}$ & $\begin{array}{l}721 \\
10 \\
9\end{array}$ & $\begin{array}{l}97.4 \\
1.4 \\
1.2\end{array}$ \\
\hline $\begin{array}{l}\text { K5. COVID-19 can cause multiple } \\
\text { infections. }\end{array}$ & $\begin{array}{l}\text { Yes } \\
\text { No } \\
\text { I do not } \\
\text { know }\end{array}$ & $\begin{array}{l}1 \\
0 \\
0\end{array}$ & $\begin{array}{l}615 \\
37 \\
88\end{array}$ & $\begin{array}{l}83.1 \\
5 \\
11.9\end{array}$ \\
\hline $\begin{array}{l}\text { K6. COVID- } 19 \text { is a fatal disease for any } \\
\text { individual. }\end{array}$ & $\begin{array}{l}\text { Yes } \\
\text { No } \\
\text { I do not } \\
\text { know }\end{array}$ & $\begin{array}{l}0 \\
1 \\
0\end{array}$ & $\begin{array}{l}215 \\
473 \\
52\end{array}$ & $\begin{array}{l}29.1 \\
63.9 \\
7\end{array}$ \\
\hline $\begin{array}{l}\text { K7. Individuals with chronic medical } \\
\text { illnesses are considered a high-risk group } \\
\text { for COVID-19. }\end{array}$ & $\begin{array}{l}\text { Yes } \\
\text { No } \\
\text { I do not } \\
\text { know }\end{array}$ & $\begin{array}{l}1 \\
0 \\
0\end{array}$ & $\begin{array}{l}690 \\
23 \\
27\end{array}$ & $\begin{array}{l}93.2 \\
3.1 \\
3.6\end{array}$ \\
\hline $\begin{array}{l}\text { K8. Effective treatment for COVID-19 is } \\
\text { currently available. }\end{array}$ & $\begin{array}{l}\text { Yes } \\
\text { No } \\
\text { I do not } \\
\text { know }\end{array}$ & $\begin{array}{l}0 \\
1 \\
0\end{array}$ & $\begin{array}{l}50 \\
512 \\
178\end{array}$ & $\begin{array}{l}6.8 \\
69.2 \\
24.1\end{array}$ \\
\hline $\begin{array}{l}\text { K9. A vaccine for COVID-19 is currently } \\
\text { available. }\end{array}$ & $\begin{array}{l}\text { Yes } \\
\text { No } \\
\text { I do not } \\
\text { know }\end{array}$ & $\begin{array}{l}0 \\
1 \\
0\end{array}$ & $\begin{array}{l}45 \\
527 \\
168\end{array}$ & $\begin{array}{l}6.1 \\
71.2 \\
22.7\end{array}$ \\
\hline $\begin{array}{l}\text { KIO. Do you know how long it can take } \\
\text { for an individual to become sick after } \\
\text { exposure to COVID-19? }\end{array}$ & $\begin{array}{l}\text { Yes } \\
\text { No } \\
\text { I do not } \\
\text { know }\end{array}$ & $\begin{array}{l}1 \\
0 \\
0\end{array}$ & $\begin{array}{l}647 \\
35 \\
58\end{array}$ & $\begin{array}{l}87.4 \\
4.7 \\
7.8\end{array}$ \\
\hline
\end{tabular}

Abbreviations: $\mathrm{N}$, number of participants; \%, percentage; COVID-19, coronavirus disease 2019; KI, knowledge question-I; K2, knowledge question-2; K3, knowledge question-3; K4, knowledge question-4; K5, knowledge question-5; K6, knowledge question-6; K7, knowledge question-7; K8, knowledge question-8; K9, knowledge question-9; KI0, knowledge question- 10.

participants had higher scores for item K7 (see Table 3). Finally, the main sources of COVID-19 information were the MOH website $(661,89.3 \%)$, social media $(256,34.6 \%)$, the WHO (246, 33.2\%), and family and friends (80, 10.81\%). 


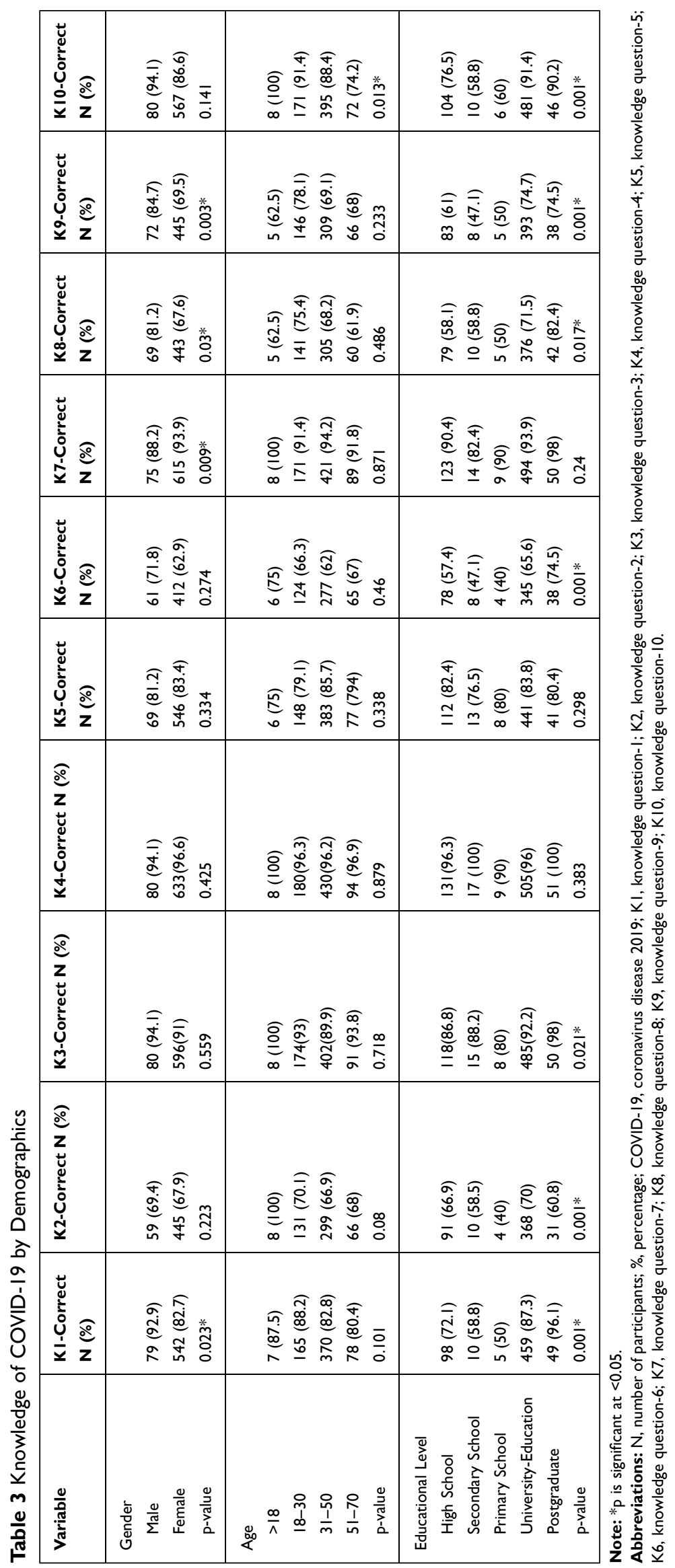


Table 4 Attitude Toward COVID-19

\begin{tabular}{|c|c|c|c|c|}
\hline Variable & Options & Score & $\mathbf{N}$ & (\%) \\
\hline $\begin{array}{l}\text { Al. Are you worried that your } \\
\text { family members might be } \\
\text { infected? }\end{array}$ & $\begin{array}{l}\text { Yes } \\
\text { Sometimes } \\
\text { No }\end{array}$ & $\begin{array}{l}2 \\
1 \\
0\end{array}$ & $\begin{array}{l}547 \\
136 \\
57\end{array}$ & $\begin{array}{l}73.9 \\
18.4 \\
7.7\end{array}$ \\
\hline $\begin{array}{l}\text { A2. The transmission of } \\
\text { COVID-19 can be prevented } \\
\text { by using standard and isolation } \\
\text { precautions provided by the } \\
\text { WHO. }\end{array}$ & $\begin{array}{l}\text { Yes } \\
\text { May be } \\
\text { No }\end{array}$ & $\begin{array}{l}2 \\
1 \\
0\end{array}$ & $\begin{array}{l}708 \\
29 \\
3\end{array}$ & $\begin{array}{l}95.7 \\
3.9 \\
0.4\end{array}$ \\
\hline $\begin{array}{l}\text { A3. The prevalence of COVID- } \\
19 \text { can be reduced by the } \\
\text { active participation of health } \\
\text { care workers in hospital } \\
\text { infection control programs. }\end{array}$ & $\begin{array}{l}\text { Yes } \\
\text { May be } \\
\text { No }\end{array}$ & $\begin{array}{l}2 \\
1 \\
0\end{array}$ & $\begin{array}{l}416 \\
224 \\
100\end{array}$ & $\begin{array}{l}56.2 \\
30.3 \\
13.5\end{array}$ \\
\hline $\begin{array}{l}\text { A4. If a COVID- } 19 \text { vaccine } \\
\text { were available, would you take } \\
\text { it? }\end{array}$ & $\begin{array}{l}\text { Yes } \\
\text { May be } \\
\text { No }\end{array}$ & $\begin{array}{l}2 \\
1 \\
0\end{array}$ & $\begin{array}{l}495 \\
169 \\
76\end{array}$ & $\begin{array}{l}66.9 \\
22.8 \\
10.3\end{array}$ \\
\hline $\begin{array}{l}\text { A5. Are you worried about the } \\
\text { rise in the death toll? }\end{array}$ & $\begin{array}{l}\text { Yes } \\
\text { Sometimes } \\
\text { No }\end{array}$ & $\begin{array}{l}2 \\
1 \\
0\end{array}$ & $\begin{array}{l}499 \\
142 \\
99\end{array}$ & $\begin{array}{l}67.4 \\
19.2 \\
13.4\end{array}$ \\
\hline $\begin{array}{l}\text { A6. Do you think it is } \\
\text { necessary to increase the } \\
\text { knowledge level concerning } \\
\text { COVID-19? }\end{array}$ & $\begin{array}{l}\text { Yes } \\
\text { May be } \\
\text { No }\end{array}$ & $\begin{array}{l}2 \\
1 \\
0\end{array}$ & $\begin{array}{l}530 \\
118 \\
92\end{array}$ & $\begin{array}{l}71.6 \\
15.9 \\
12.4\end{array}$ \\
\hline
\end{tabular}

Abbreviations: N, number of participants; \%, percentage; COVID-19, coronavirus disease 2019; $\mathrm{Al}$, attitude question-I; $\mathrm{A} 2$, attitude question-2; $\mathrm{A} 3$, attitude question-3; A4, attitude question-4; A5, attitude question-5; A6, attitude question-6.

\section{Attitude Toward COVID-19}

Participants' general attitude toward COVID-19 was tested using six single-choice questions with the scores listed in Table 4 . The percentage of the correct answers was $81.16 \%$ $(9.74 / 12 * 100)$. The mean attitude score was $9.74 \pm 1.935$; the median attitude score was 10 (range $=2-12$ ). Overall, $95.7 \%$ of the participants agreed that using standard and isolation precautions provided by the WHO can prevent the transmission of COVID-19, while 416 (56.2\%) agreed that the prevalence of COVID-19 can be reduced by the active participation of health-care workers in hospital infection control programs. The other responses are listed in Table 5. A significant difference between the female and male scores regarding items $\mathrm{A} 1, \mathrm{~A} 2$, and $\mathrm{A} 3$ was found, with more male participants providing the correct answers for $\mathrm{A} 1$ and $\mathrm{A} 3$ and more female participants providing the correct answer for A2. Participants in the age group 18-30 had significantly higher scores for items A1 and A4 than other age groups. No statistically significant difference was found among participants from different educational levels, except for item A3 (see Table 5).

\section{Precautionary Measures Against COVID-19}

The percentage of the correct answers to the six questions on the COVID-19 precautionary measures questionnaire was $90.83 \%(10.9 / 12 * 100)$. The mean precautionary measures score was $10.90 \pm 1.91$, whereas the median precautionary measures score was 10 (range $=3-12$ ). The participants proved to be using the appropriate precautionary measures against COVID-19, as 562 (75.9\%) are washing their hands with soap for about 20 seconds; 429 $(58 \%)$ and $528(71.4 \%)$ are also wearing protective masks and gloves when they leave their homes, respectively. In addition, 721 (97.4) and 511 (69.1\%) of the participants stopped attending social events and going to the supermarkets, respectively. Most of the participants are following the instructions of the $\mathrm{MOH}$ (see Table 6).

Female participants had significantly higher precautionary measures scores than male participants for items P2, P3, P4, and P5. No significant difference was found between different age groups, except for P5, since more participants were in the $31-50$ age group precautionary measures the correct response. The educational level indicated no significant difference in the precautionary measures used against COVID-19 (see Table 7).

\section{Discussion}

As of August 23, 213, 489 confirmed cases of COVID-19 had been reported worldwide, including 804,556 deaths. In Saudi Arabia, 307,479 cases have been confirmed, and in the Aseer Region, 23,635. In our study, most participants had a high level of knowledge regarding COVID-19. Indeed, $97.4 \%$ and $68.1 \%$ of them know the transmission methods and symptoms of COVID-19, respectively. This high level of knowledge could have resulted from the Saudi MOH's efforts to increase public knowledge of this novel virus by sending mobile messages and using different means of communication, including television and social media. Furthermore, we found a significant difference in the knowledge level among different educational levels: participants with a lower educational level exhibited less knowledge than those with a higher educational level.

A similar study that Zhong et al conducted on Chinese residents also assessed participants' knowledge of COVID-19. ${ }^{17}$ Particularly their knowledge of the clinical 
Table 5 Attitude Toward COVID-19 by Demographics

\begin{tabular}{|c|c|c|c|c|c|c|}
\hline Variable & $\begin{array}{l}\text { Al-Correct } \\
\text { N (\%) }\end{array}$ & A2-Correct N (\%) & A3-Correct N (\%) & A4-Correct N (\%) & $\begin{array}{l}\text { A5-Correct } \\
\text { N (\%) }\end{array}$ & A6-Correct N (\%) \\
\hline \multicolumn{7}{|l|}{ Gender } \\
\hline Male & $70(82.4)$ & $76(89.4)$ & 61 (7I.8) & 61 (7I.8) & $53(62.4)$ & $65(76.5)$ \\
\hline Female & 477 (72.8) & $632(96.5)$ & $355(54.2)$ & $434(66.3)$ & $446(68.1)$ & 465 (7I) \\
\hline $\mathrm{p}$-value & $0.036^{*}$ & $0.01^{*}$ & $0.002 *$ & 0.581 & 0.163 & $0.57 I$ \\
\hline \multicolumn{7}{|l|}{ Age } \\
\hline$>18$ & $5(62)$ & $8(100)$ & $4(50)$ & $6(75)$ & $7(87.5)$ & $8(100)$ \\
\hline $18-30$ & $149(79.7)$ & $178(95.2)$ & $112(59.9)$ & 142 (75.9) & $128(68.4)$ & $139(74.3)$ \\
\hline $31-50$ & $329(73.6)$ & $426(95.3)$ & $249(55.7)$ & $285(63.8)$ & $302(67.6)$ & 318 (7I.I) \\
\hline $51-70$ & $64(66)$ & $95(97.9)$ & $50(5 \mid .5)$ & $62(63.9)$ & $62(63.9)$ & $65(67)$ \\
\hline $\mathrm{P}$-value & $0.002^{*}$ & 0.981 & 0.560 & $0.018^{*}$ & 0.206 & 0.148 \\
\hline \multicolumn{7}{|l|}{ Educational Level } \\
\hline High School & $93(68.4)$ & $126(92.6)$ & $63(46.3)$ & $87(64)$ & 91 (66.7) & $98(72.1)$ \\
\hline Secondary School & $15(88.2)$ & $17(100)$ & $6(35.3)$ & $12(70.6)$ & II (64.7) & $13(76.5)$ \\
\hline Primary School & $9(90)$ & $10(100)$ & $9(90)$ & $10(100)$ & $7(70)$ & $6(60)$ \\
\hline University-Education & $390(74.1)$ & 507 (96.4) & $307(58.4)$ & $354(67.3)$ & 351 (66.7) & 377 (7I.7) \\
\hline Postgraduate & $40(78.4)$ & $48(94.1)$ & $31(60.8)$ & $32(62.7)$ & $39(76.5)$ & $36(70.6)$ \\
\hline p-value & 0.395 & 0.594 & $0.003^{*}$ & 0.09 & 0.402 & 0.972 \\
\hline
\end{tabular}

Note: ${ }^{*} p$ is significant at $<0.05$.

Abbreviations: N, number of participants; \%, percentage; COVID-19, coronavirus disease 20I9; AI, attitude question-I; A2, attitude question-2; A3, attitude question-3; $\mathrm{A} 4$, attitude question-4; $\mathrm{A}$, attitude question-5; $\mathrm{A} 6$, attitude question-6.

Table 6 Precautionary Measures Against COVID-19 Among Residents of the Aseer Region

\begin{tabular}{|c|c|c|c|c|}
\hline Variable & Options & Score & $\mathbf{N}$ & (\%) \\
\hline $\begin{array}{l}\text { PI. Do you wash your hands } \\
\text { for } 20 \text { seconds? }\end{array}$ & $\begin{array}{l}\text { Yes } \\
\text { Sometimes } \\
\text { No }\end{array}$ & $\begin{array}{l}2 \\
1 \\
0\end{array}$ & $\begin{array}{l}562 \\
146 \\
32\end{array}$ & $\begin{array}{l}75.9 \\
19.7 \\
4.3\end{array}$ \\
\hline $\begin{array}{l}\text { P2. Do you wear a protective } \\
\text { face mask when you leave your } \\
\text { home? }\end{array}$ & $\begin{array}{l}\text { Yes } \\
\text { Sometimes } \\
\text { No }\end{array}$ & $\begin{array}{l}2 \\
1 \\
0\end{array}$ & $\begin{array}{l}429 \\
111 \\
200\end{array}$ & $\begin{array}{l}58.0 \\
15.0 \\
27.0\end{array}$ \\
\hline $\begin{array}{l}\text { P3. Do you wear protective } \\
\text { gloves when you leave your } \\
\text { home? }\end{array}$ & $\begin{array}{l}\text { Yes } \\
\text { Sometimes } \\
\text { No }\end{array}$ & $\begin{array}{l}2 \\
1 \\
0\end{array}$ & $\begin{array}{l}528 \\
102 \\
110\end{array}$ & $\begin{array}{l}71.4 \\
13.8 \\
14.9\end{array}$ \\
\hline $\begin{array}{l}\text { P4. Do you still attend social } \\
\text { events? }\end{array}$ & $\begin{array}{l}\text { Yes } \\
\text { Sometimes } \\
\text { No }\end{array}$ & $\begin{array}{l}0 \\
1 \\
2\end{array}$ & $\begin{array}{l}9 \\
10 \\
721\end{array}$ & $\begin{array}{l}1.2 \\
1.4 \\
97.4\end{array}$ \\
\hline $\begin{array}{l}\text { P5. Have you stopped going to } \\
\text { the supermarkets and tried } \\
\text { online shopping? }\end{array}$ & $\begin{array}{l}\text { Yes } \\
\text { Sometimes } \\
\text { No }\end{array}$ & $\begin{array}{l}2 \\
1 \\
0\end{array}$ & $\begin{array}{l}511 \\
160 \\
69\end{array}$ & $\begin{array}{l}69.1 \\
21.6 \\
9.3\end{array}$ \\
\hline $\begin{array}{l}\text { P6. Do you follow the } \\
\text { instructions of the } \mathrm{MOH} \text { ? }\end{array}$ & $\begin{array}{l}\text { Yes } \\
\text { Sometimes } \\
\text { No }\end{array}$ & $\begin{array}{l}2 \\
1 \\
0\end{array}$ & $\begin{array}{l}698 \\
37 \\
5\end{array}$ & $\begin{array}{l}94.3 \\
5.0 \\
0.7\end{array}$ \\
\hline
\end{tabular}

Abbreviations: N, number of participants; \%, percentage; COVID-19, coronavirus disease 2019; PI, precautionary measures question-I; P2, precautionary measures question-2; P3, precautionary measures question-3; P4, precautionary measures question-4; P5, precautionary measures question-5; P6, precautionary measures question-6. characteristics and prevention of the virus. In their study, the authors reported that most of the respondents $(90 \%)$ were knowledgeable about COVID-19, consistent with the results of our study. Similarly, a study by Peng et al that assessed Chinese University students' knowledge regarding COVID-19 reported that most of the participants $(82.34 \%)$ had a basic knowledge of this disease. ${ }^{23}$ Another study by Hussain et al reported that Nepalese residents exhibited satisfactory knowledge. ${ }^{18} \mathrm{~A}$ similar study that Abdelhafiz et al conducted assessed Egyptians' overall attitude toward and knowledge and perceptions of this novel coronavirus disease and reported that the participants generally had good knowledge, which is consistent with our study; however, these authors also reported that knowledge on this topic was significantly lower among older, less-educated, lower-income participants and rural residents. ${ }^{20}$ Nevertheless, another study that Rahman et al conducted on the Internet users of Bangladesh stated that the participants' knowledge and preventive practices were encouraging, and the authors suggested that health-care authorities must provide updated knowledge to enhance the appropriate preventive practices throughout the COVID-19 outbreak. ${ }^{24}$ Some more studies assessed their participants' knowledge, but 
Table 7 Precautionary Measures Toward COVID-19 by Demographics

\begin{tabular}{|c|c|c|c|c|c|c|}
\hline Variable & $\begin{array}{l}\text { PI-Correct } \\
\text { N (\%) }\end{array}$ & P2-Correct N (\%) & P3-Correct N (\%) & P4-Correct N (\%) & $\begin{array}{l}\text { P5-Correct } \\
\text { N (\%) }\end{array}$ & $\begin{array}{l}\text { P6-Correct } \\
\text { N (\%) }\end{array}$ \\
\hline \multicolumn{7}{|l|}{ Gender } \\
\hline Male & $62(72.9)$ & $33(38.8)$ & 31 (36.5) & 74 (87.I) & 35 (4I.2) & 72 (84.7) \\
\hline Female & $500(76.3)$ & $396(60.5)$ & 497 (75.9) & $647(98.8)$ & $476(72.7)$ & $626(95.6)$ \\
\hline $\mathrm{P}$-value & 0.411 & $0.00 I^{*}$ & $0.001 *$ & $0.00 I^{*}$ & $0.001 *$ & 0.571 \\
\hline \multicolumn{7}{|l|}{ Age } \\
\hline$>18$ & $8(100)$ & $6(75)$ & $5(62.5)$ & $7(87.5)$ & $4(50)$ & $8(100)$ \\
\hline $18-30$ & $135(72.2)$ & $105(56.1)$ & $123(65.8)$ & $180(96.3)$ & $127(67.9)$ & $176(94.1)$ \\
\hline $31-50$ & $34 I(76.3)$ & $261(58.4)$ & $329(73.6)$ & $438(98)$ & $325(72.7)$ & $422(94.4)$ \\
\hline $5 \mathrm{I}-70$ & $77(79.4)$ & $56(57.7)$ & $70(72.2)$ & $95(97.9)$ & $54(55.7)$ & 91 (93.8) \\
\hline $\mathrm{P}$-value & 0.605 & 0.981 & 0.05 & 0.144 & $0.01 *$ & 0.99 \\
\hline \multicolumn{7}{|l|}{ Educational level } \\
\hline High School & 107 (78.7) & $74(54.4)$ & $94(69.1)$ & $133(97.8)$ & $98(72.1)$ & $128(94.1)$ \\
\hline Secondary School & $562(75.9)$ & $10(58.8)$ & $14(82.4)$ & $17(100)$ & $9(52.9)$ & $16(94.1)$ \\
\hline Primary School & $7(70)$ & $6(60)$ & $8(80)$ & $9(90)$ & $6(60)$ & $10(100)$ \\
\hline University-Education & $395(75.1)$ & $312(59.3)$ & 381 (72.4) & $513(97.5)$ & $364(69.2)$ & $496(94.1)$ \\
\hline Postgraduate & $39(76.5)$ & $27(52.9)$ & $31(60.8)$ & $49(96.1)$ & $34(66.7)$ & $48(94.1)$ \\
\hline $\mathrm{p}$-value & 0.654 & 0.86 & 0.006 & 0.226 & 0.648 & 0.955 \\
\hline
\end{tabular}

Note: ${ }^{*} \mathrm{p}$ is significant at $<0.05$.

Abbreviations: N, number of participants; \%, percentage; COVID-19, coronavirus disease 2019; PI, precautionary measures question-I; P2, precautionary measures question-2; P3, precautionary measures question-3; P4, precautionary measures question-4; P5, precautionary measures question-5; P6, precautionary measures question-6.

their studies included health-care workers instead of community residents. ${ }^{25,26}$

Regarding our participants' overall attitude toward COVID-19, $81.16 \%$ of them demonstrated a positive attitude. About three-quarters of them were worried about the risk of infection for their family members, especially the elderly. Besides, $95.5 \%$ of them agreed that the transmission of COVID-19 could be prevented by using standard and isolation precautions provided by the $\mathrm{WHO}$, while $66.9 \%$ seem willing to take the vaccine once it becomes available. Our results are consistent with those of Abdelhafiz et al, which indicated a high positive attitude toward COVID-19 among Egyptian populations. ${ }^{20}$ Another study conducted on Chinese residents confirmed that the participants held an optimistic attitude toward COVID-19. ${ }^{26}$

Most individuals who fall sick with COVID-19 experience mild to moderate symptoms at the beginning of the infection, highlighting the importance of using precautionary measures, such as wearing gloves and face masks when going outside. As a face mask covers the mouth and nose, it should protect healthy individuals and prevent sick individuals from transmitting the virus through droplets while sneezing or coughing. COVID-19 is mainly transmitted through droplets. Since the virus is too heavy to hang in the air, it falls on surfaces and floors; wearing gloves will protect individuals from coming in direct contact with contaminated surfaces. ${ }^{27}$

Despite the WHO's recommendation to use face masks only if an individual has respiratory symptoms or is caring for another individual with symptoms, the Centers for Disease Control and Prevention recently recommended using cloth face coverings. ${ }^{27,28}$ In this study, as we assessed the community's level of using precautionary measures against COVID-19, we found that the participants have used a high level of precautionary measures (90.83\%), which could be attributed to their high level of knowledge concerning the severity of the virus and the complication that can develop if an individual becomes infected. Most of the participants have been wearing protective gloves and face masks; they are no longer attending social events and have started reducing their trips to the supermarkets, trying online shopping instead. These results are consistent with those presented in other countries, which also indicate high levels of using precautionary measures among Chinese residents and Chinese students during the rapid rise of the COVID-19 outbreak. ${ }^{23,26}$ Furthermore, we found that female participants have been using more precautionary measures than male participants. This finding has been verified by many other 
studies stating that women are using more appropriate precautionary measures than men in the case of infectious disease. ${ }^{23,26}$ However, the age and educational level differences among the Aseer Region residents did not significantly affect their precautionary measures against COVID-19. This could be due to the simplicity of the information provided by the $\mathrm{MOH}$, which has allowed individuals from different age groups and educational levels to understand it.

This study has certain limitations that should be addressed in future research: Since the participants were recruited using a convenience sampling method, the sample might not represent the entire population. Furthermore, the study includes only residents of the Aseer Region, and the results thus cannot be generalized to the whole of Saudi Arabia. The study design was a cross-sectional study that does not allow to draw a causal inference and thus provides a lower quality of evidence in comparison to longitudinal studies. However, it is to note that a longitudinal study was not a feasible option with the situation of social distancing and lockdown implemented throughout the nation at the time of the study.

\section{Conclusion}

In summary, this study confirms that residents of the Aseer Region, Saudi Arabia, have good knowledge of, demonstrate a positive attitude toward, and use appropriate precautionary measures against COVID-19, which is associated with obtaining information about the virus from the $\mathrm{MOH}$ website. Despite the high level of knowledge among our participants, it is recommended that the same precautionary measures be maintained not to become bored and that the general knowledge level be improved by finding alternative forms of communication with low-educated groups.

\section{Acknowledgments}

The authors are extremely grateful to the residents of the Aseer Region who so kindly contributed their time to participate in this study. The authors are also indebted to Rahaf Hasan Mutiq and Wejdan Fahad Ali Alshehri, who helped to collect the data. The authors are grateful to King Khalid University.

\section{Disclosure}

The authors declare no conflicts of interest for this work.

\section{References}

1. The Novel Coronavirus Pneumonia Emergency Response Epidemiology Team. The epidemiological characteristics of an outbreak of 2019 novel coronavirus diseases (COVID-19) in China. Chin J Epidemiol. 2020;41:145-151.
2. Chen N, Zhou M, Dong X, et al. Epidemiological and clinical characteristics of 99 cases of 2019 novel coronavirus pneumonia in Wuhan, China: a descriptive study. Lancet. 2020;395 (10223):507-513. doi:10.1016/S0140-6736(20)30211-7

3. Zhou P, Yang XL, Wang XG, et al. Discovery of a novel coronavirus associated with the recent pneumonia outbreak in humans and its potential bat origin. bioRxiv. 2020.

4. World Health Organization. Coronavirus disease (COVID-2019) situation reports-209; 2020. Available from: https://www.who.int/ docs/default-source/coronaviruse/situation-reports/20200816-covid -19-sitrep-209.pdf?sfvrsn=5dde1ca2_2. Accessed September 9, 2020.

5. World Health Organization. 2019-nCoV outbreak is an emergency of international concern; 2020. Available from: http://www.euro.who. int/en/health-topics/emergencies/pages/news/news/2020/01/2019ncov-outbreak-is-an-emergency-of-international-concern. Accessed September 9, 2020.

6. World Health Organization. Coronavirus disease (COVID-2019) situation reports; 2020. Available from: https://www.who.int/docs/ default-source/coronaviruse/situation-reports/20200303-sitrep-43covid-19.pdf?sfvrsn=76e425ed_2. Accessed September 9, 2020.

7. World Health Organization. Coronavirus disease (COVID-2019) situation reports; 2020. Available from: https://www.who.int/docs/ default-source/coronaviruse/situation-reports/20200513-covid-19sitrep-114.pdf?sfvrsn=17ebbbe_4. Accessed September 9, 2020.

8. Chan J, Yuan S, Kok K, et al. A familial cluster of pneumonia associated with the 2019 novel coronavirus indicating person-toperson transmission: a study of a family cluster. Lancet. 2020;395 (10223):514-523. doi:10.1016/s0140-6736(20)30154-9

9. Wilder-Smith A, Freedman D. Isolation, quarantine, social distancing and community containment: pivotal role for old-style public health measures in the novel coronavirus (2019-nCoV) outbreak. J Travel Med. 2020;27(2). doi:10.1093/jtm/taaa020

10. Ebrahim S, Memish Z. Saudi Arabia's drastic measures to curb the COVID-19 outbreak: temporary suspension of the Umrah pilgrimage. J Travel Med. 2020;27(3). doi:10.1093/jtm/taaa029

11. Ministry of Education. Moe.gov.sa. Available from: https://www. moe.gov.sa/ar/Pages/default.aspx. Accessed August 22, 2020.

12. The official Saudi Press Agency. Spa.gov.sa. Available from: https:// www.spa.gov.sa/?lang=en. Accessed August 22, 2020.

13. Chirwa G. Socio-economic inequality in comprehensive knowledge about HIV in Malawi. Malawi Med J. 2019;31(2):104. doi:10.4314/ mmj.v31i2.1

14. Ministry of Health. Statistical yearbook 1439H. Kingdom of Saudi Arabia; 2018. Available from: https://www.moh.gov.sa/en/Ministry/ Statistics/book/Documents/StatisticalBook-1439.pdf. Accessed Aug 13, 2020.

15. Althobaity HM, Alharthi RAS, Altowairqi MH, et al. Knowledge and awareness of Middle East respiratory syndrome coronavirus among Saudi and Non-Saudi Arabian pilgrims. Int J Health Sci (Qassim). 2017;11(5):20-25.

16. Bawazir A, Al-Mazroo E, Jradi H, Ahmed A, Badri M. MERS-CoV infection: mind the public knowledge gap. J Infect Public Health. 2018;11(1):89-93. doi:10.1016/j.jiph.2017.05.003

17. Zhong B, Luo W, Li H, et al. Knowledge, attitudes, and practices towards COVID-19 among Chinese residents during the rapid rise period of the COVID-19 outbreak: a quick online cross-sectional survey. Int $J$ Biol Sci. 2020;16(10):1745-1752. doi:10.7150/ ijbs. 45221

18. Hussain A, Garima T, Singh B, Ram R, Tripti R. Knowledge, attitudes, and practices towards COVID-19 among Nepalese residents: a quick online cross-sectional survey. Asian J Med Sci. 2020;11 (3):6-11. doi:10.3126/ajms.v11i3.28485

19. Bener A, Al-Khal A. Knowledge, attitude and practice towards SARS. J R Soc Promot Health. 2004;124(4):167-170. doi:10.1177/ 146642400412400408 
20. Abdelhafiz A, Mohammed Z, Ibrahim M, et al. Knowledge, perceptions, and attitude of Egyptians towards the novel coronavirus disease (COVID-19). J Community Health. 2020;45(5):881-890. doi:10.1007/s10900-020-00827-7

21. Nahida A. Knowledge, Attitude and Practice of Dengue Fever Prevention Among the People in Male, Maldives [published master's dissertation]. Thailand: Chulalongkorn University; 2007.

22. Akalu Y, Ayelign B, Molla MD. Knowledge, attitude and practice towards COVID-19 among chronic disease patients at Addis Zemen Hospital, Northwest Ethiopia. Infect Drug Resist. 2020;13:1949-1960. doi:10.2147/IDR.S258736

23. Peng Y, Chenchen P, Zheng Y, et al. Knowledge, Attitude and Practice Associated with COVID-19 Among University Students: A Cross-Sectional Survey in China. 2020.

24. Rahman A, Sathi N. Knowledge attitude, and preventive practices toward COVID-19 among Bangladeshi internet users. Electron J Gen Med. 2020;17(5):em245. doi:10.29333/ejgm/8223
25. Zhang M, Zhou M, Tang F, et al. Knowledge, attitude, and practice regarding COVID-19 among healthcare workers in Henan, China. $J$ Hosp Infect. 2020;105(2):183-187. doi:10.1016/j.jhin.2020.04.012

26. Huynh G, Nguyen TN, Tran VK, Vo KN, Vo VT, Pham LA. Knowledge and attitude toward COVID-19 among healthcare workers at district 2 hospital, Ho Chi Minh City. Asian Pac J Trop Med. 2020;13:260-265.

27. Recommendation regarding the use of cloth face coverings, especially in areas of significant community-based transmission; 2020. Available from: https:/www.cdc.gov/coronavirus/2019-ncov/preventgetting-sick/cloth-face-coverhtml.

28. Coronavirus disease (COVID-19) advice for the public: when and how to use masks; 2020. Available from: https://www.who.int/emer gencies/diseases/novel-coron avirus-2019/advice-for-public/whenand-how-to-use-masks.
Risk Management and Healthcare Policy

\section{Publish your work in this journal}

Risk Management and Healthcare Policy is an international, peerreviewed, open access journal focusing on all aspects of public health, policy, and preventative measures to promote good health and improve morbidity and mortality in the population. The journal welcomes submitted papers covering original research, basic science, clinical \& epidemiological studies, reviews and evaluations,

\section{Dovepress}

guidelines, expert opinion and commentary, case reports and extended reports. The manuscript management system is completely online and includes a very quick and fair peer-review system, which is all easy to use. Visit http://www.dovepress.com/testimonials.php to read real quotes from published authors. 